\title{
Empirical Entrepreneurship Oriented Reforms on E-Commerce Teaching
}

\author{
Ming-Yan WANG \\ Department of Information Management \\ School of Management \\ Shanghai University of Engineering Science \\ Shanghai, China \\ wmy61610@126.com
}

\author{
Shu-Ge TIAN, Rui ZHANG \\ Department of Information Management \\ School of Management \\ Shanghai University of Engineering Science \\ Shanghai, China
}

\begin{abstract}
As one of essential core courses in the College of Management, E-Commerce is the course with stronger effectiveness and more practicality in comparison with other courses. To solve the main problems and shortcomings in teaching strategies and methods for E-Commerce curriculum theory and practice teaching system at present, combined with new developments in the field of electronic commerce, the paper proposes the Empirical Entrepreneurship Oriented Reforms on the E-Commerce Teaching to meet the needs of new social media for application-oriented talents in teaching process, teaching methods, and other aspects of practical application.
\end{abstract}

Keywords-empirical entrepreneurship; e-commerce curriculum; teaching reform; practice ability

\section{INTRODUCTION}

The development of network economy led to huge demand for e-commerce-related talents. E-commerce is an interdisciplinary course, which is a disciplines basic platform course of information management and information systems, logistics management, marketing, business management, project management, international economy and trade and other profession.

With the application of information technology in enterprises, new technology, new thinking, new patterns and new applications under the network economy constantly rich the connotation of e-commerce, such as mobile commerce, social media, etc. all of which is the hot points of acknowledge in the international e-commerce area. When WEB 2.0 technology changed the way to spread the information, it also make more businesses and individuals can take use of the social media platform for entrepreneurship, so it also adds further study teaching content and methods for The practice teaching modules. As the "Electronic Commerce" introduction course is compared to other courses with the stronger effectiveness and practicality [1]. So in the course of theory and practice teaching system, there is still a research space which is worthy of further exploring, improving and perfecting.

Sponsor: The Project for Core Courses Construction with E-commerce sponsored by Shanghai Municipal Education Commission（s201503003）

\section{II.THE REVIEW ON THE STUDIES ABOUT THE STATUS OF E- COMMERCE TEACHING REFORM}

E-commerce is an interdisciplinary course, that the curriculum content knowledge covers three knowledge dimensions: behavior, technology and management.

\section{(A) Behavior}

It is major content in studying the behavior characteristics in the e-commerce human process, analyzing the different networks groups' shopping mode, preferences and personality characteristics, etc. Through the analysis of human behavior, the further refinement of the guiding and humanized principles in the e-commerce process makes ecommerce more targeted, more effective. The main intellectual content includes the network marketing's analysis, planning, marketing, advertising and so on.

\section{(B) Technology}

Technology mainly realize the e-commerce process from the technical level, use it to make transactions more secure, reliable, and make function more perfect, more intelligent and so on. The main knowledge content includes EDI (Electronic Data Interchange), intelligent agents, intelligent search, customer relationship management and e-commerce transactions in the field of information security.

\section{(C) Management}

E-commerce is not just a sales based on the networks, the true e-commerce should be widely used and accompanied by the advance of new management ideas and management methods. Such as supply chain management, ERP(Enterprise Resource Planning), etc. through the integration of internal and external resources as well as network-based enterprise management, it makes business processes update or change.

The course group of teachers on E-Commerce has been researching on the CNKI(China National Knowledge Infrastructure) and Wan Fang database by using keywords "E-commerce course" and "practical ability" to get much information about e-commerce curriculum reform related researches, the result as shown in "Figure 1". 


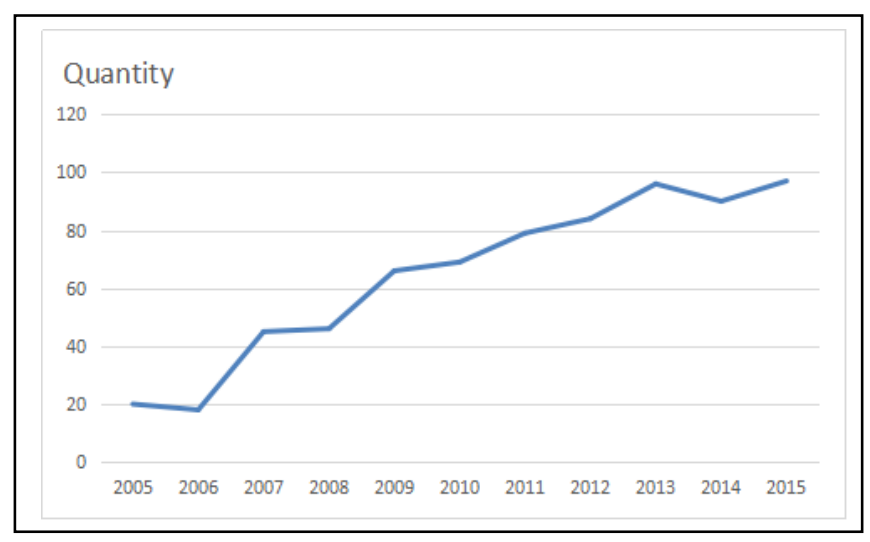

Figure 1. The statistics of literature for studies in the teaching reforms.

According to the statistics and analysis of the status on Chinese electronic commerce's course development in Internet, Scholars' researches mostly concentrate on the content of the reform of the e-commerce practice ability under the background of new media. At present, improving teaching methods and strengthening hands-on experience based on the new media technology, furthermore, closely combining with college students enterprising activities have been becoming a hot research topic in the E-Commerce course teaching practice.

\section{III.THE MAIN PROBLEMS WITH WHICH THE CURRICULUM KNOWLEDGE IS FACED}

Course knowledge system of e-commerce need to be closely related to reality, at present, the main problems that exist in this course are:

\section{(A) Theoretical teaching is overweight, lacking practical training in real industry}

E-commerce is a comprehensive interdisciplinary which is closely related to management, economics, computer science and other disciplines, involving multiple disciplines theory, but too much emphasis on the theory of multidisciplinary in the process of teaching, makes the knowledge complex, fragmented, and easy to let the course teaching is a theory patchwork.

In the current teaching process of e-commerce Introduction, the methods of teaching practice generally go through the simple verification experiment only by the simulation software, web browsing and so on which led to less effective practice, limited practice activities out touch of reality. In this training mode, it's difficult for students to experience the real e-commerce transactions and improve the actual operational capacity effectively, which always enable students to stay in the shallow, as well as never come into contact with the essence of e-commerce.

\section{(B) Simple teaching methods, lacking innovative approaches}

With the rapidly changing of the e-commerce development, teaching mode must adapt to development in order to achieve teaching effectiveness and teaching purposes. The reality of e-commerce course patterns is still confined to a finite classroom space, using traditional teaching methods, which is based on classroom teaching, supplied by multimedia teaching and case teaching on the class, homeworking exercise after school for students' consolidation of the knowledge [2]. This single way of teaching emphasis too much on the leading role of teachers while ignoring students' initiative, which can't make the students to analyze and solve problems of initiative into full play, and make the original lively and interesting ecommerce curriculum become plain boring. The fast change of e-commerce development requires the use of new media technology organization of teaching activities, for which teachers' methods and tools are put forward higher requirements.

\section{(C) Rigid teaching mode, lacking actual hands-on experience and industrial training}

At present, teaching methods take full use of "entrepreneurial type" teaching, whose obvious features are that at the departure point and destination which students can learn, master and store the current knowledge, there is not the distinctive characteristics, making e-commerce courses and professional contact not closed, and teaching methods are too rigid, dogmatic, inflexible [3]. Nonadaptive and negative effects of this teaching method is more and more clearly demonstrated, and greatly hinder the student's vision, imagination and initiative. It's also lack of cultivating students' creative thinking ability, developing the potential of students and teaching students how to learn. Although being aware of the problem in the teaching process, and establishing the e-commerce laboratory systems for students' simulation exercises, the results of this teaching mode caused students learning under the passive, rigid and monotonous teaching atmosphere. The knowledge they gained and the improved ability are difficult to adapt to the demands of society, so there is the adapting contradiction between the business need of e-commerce professionals and University Professional Training talents.

\section{THE EDUCATION REFORM IDEAS AND REFORM CONTENT OF SUBJECT}

For the new development and new media technology in e-commerce area, combined with the problem this course needed to solve, this course construction plan is complied with the university needs of relevant management professional and meets the training target of school applied talents. "Electronic Commerce" reform course is located: strengthen the entrepreneurial orientation of experiential teaching mode, improving new knowledge of electronic commerce, combining the practice of experiential teaching environment and the entrepreneurial orientation to culture students who can accept combat training, strengthen ability and focus on the practice .

Based on the analysis of the present situation of ecommerce teaching, it carries out some exploration and practice in teaching content, teaching methods, teaching means and other aspects, the specific reform thought shown in "Figure 2,". 


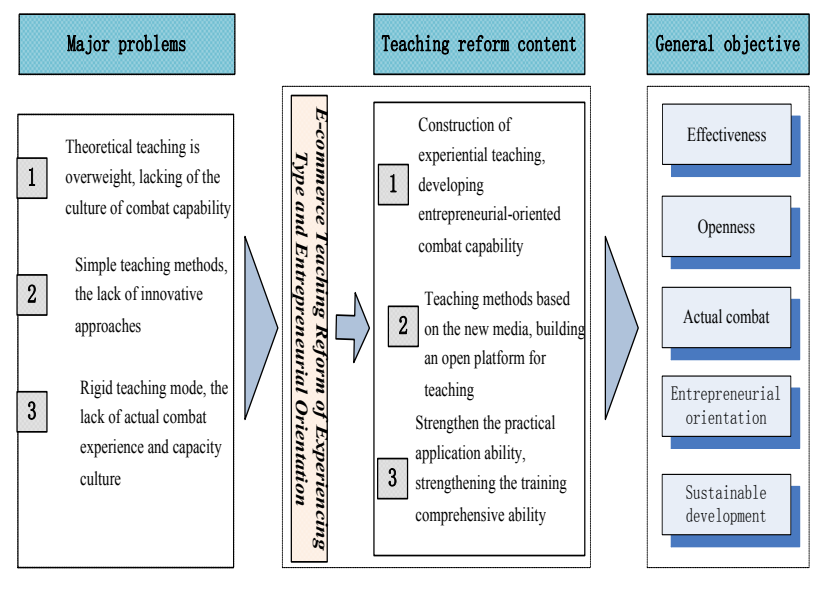

Figure 2. The Reform Schemes

\section{(A) Construction of empirical teaching, developing entrepreneurship-oriented work experiences}

There are a lot of content closely linked to practice in Ecommerce. It is a very practical course, which requires the e-commerce class teaching and practice must be combined. The link between theory and practice in the e-commerce teaching is an important way to stimulate students' interest in teaching and improving teaching efficiency. Specific teaching process can be divided into three blocks proposed:

One is based on third-party trading platform experiential teaching. Combined with the related knowledge in $\mathrm{B} 2 \mathrm{C}$, $\mathrm{B} 2 \mathrm{~B}, \mathrm{~B} 2 \mathrm{G}, \mathrm{C} 2 \mathrm{G}, \mathrm{C} 2 \mathrm{C}$ and other aspects extends in the teaching process, guide students to participate in the third trading platform trading activities. Such as Taobao, guide students to register online shops on Taobao, do the selection and procurement of goods, carry shop's decoration and display of goods according to the type of goods. These content all need them to review the e-commerce curriculum knowledge, especially network marketing and other aspects, to find products or services features which are suitable for online sales. Such a teaching Process which makes related knowledge throughout the entire business process will enable students to achieve a strong interest and to get the greatest benefit.

The second is based on teaching entrepreneurial orientation construction site. Carrying out practical aspects of the construction site based on the theory introduction of e-commerce Web development technology to enable students to understand the relationship between foreground and background of the site and how to run a website. On the construction site, it will use FrontPage, Dreamweaver and other software to create personal Web site, and improve the site by some extended knowledge. Finally, apply space domain, upload the site on the Internet to run. In the whole teaching process, it will use the related knowledge of construction site to help students to create their own commercial websites and achieve the purpose of entrepreneurship.

Third, The teaching practice based on enterprise projects. Quote the e-commerce-related business projects, so that students actually participate in e-commerce project planning, implementation and other processes [4]. By quoting the enterprise project in e-commerce courses, students can apply and consolidate the knowledge learned in the classroom in real projects, and the execution of tasks involved in the project can not only train students' ecommerce skills and ability to learn, gain the valuable actual combat experience, but also lay the foundation for the future when students take jobs. Students trained by the enterprise project-oriented teaching method, will catch the business's demand for high skilled talents and more graduates can meet the business-to-post "zero adjustment period" requirements.

\section{(B) Teaching methods based on the new media, building an open platform for teaching}

With the constant change of era, the quest of the students for knowledge is no longer satisfied with the entity classroom "teacher talk, students listen" mode. The project will build an open learning platform for students to create a diverse learning environment and atmosphere by new media.

One is the interactive teaching platform based on the social media. Taking use of the existing social media platforms, such as E-Class, provides the information download of the e-commerce curriculum's instructional videos, teaching course ware, exercises and others that students and people are interested in. At the same time according to the characteristics of curriculum set open courses forum. Students and students, students and teachers all can communicate and interact through discussion area [5]. In addition, in the era of mobile Internet, the main tool which students and teachers contact network by has been transformed from desktop computers to smart phones. So it will use the social application based on mobile intelligent terminal to complete information's exchange, the task of information push. For example, Micro-Blog can be used to forward the industry trends, expert's opinions and successful case, as a supplement to curricular learning; Use Web-Chat to set up in the public account for information push and expand teaching space and time by the microchannel communication platform.

\section{(C) Putting up the business practice application platform, strengthening the training of entrepreneurial practice ability}

Except for teaching and practical process, strengthen the control of knowledge theory by science and technology parks' practical skills areas. This course teaching reform will combine schools connotation construction and development and rely on the national university science park practice park as the part of the application from theory into practice, to explore and establish certified training aspects of e-commerce division with the enterprises in the park, realized the transformation from theory to practice, from the classroom to the workplace, from school to one who the social needs, in order to achieve the purpose of promoting the overall increase students' knowledge, ability and quality. Meanwhile guiding students to actively participate in the competition, to facilitate the teaching by race. For example, the National Students' Internet business 
application innovation contest, the "Three Hit Cup" contest of e-commerce as well as the National Mathematical Contest in Modeling, promotes students to apply the knowledge learned in the classroom. It takes advantage of race to promote learning, as well as offers help for culturing the application-oriented talents who adapt to the social development.

\section{CONCLUSIONS}

The paper is mainly focused on the empirical entrepreneurship oriented reforms on the E-commerce teaching methods and strategies under the background of new media. To establish the operational platform in the lab, set up the interactive forum based on new media, and join the projects from Sci-Tech Parks in the university, the paper has thoroughly realized the optimization of the course teaching structures in theory and practice. Therefore, it is effective, practical, open and sustainable for teachers in ECommerce to carry out empirical entrepreneurship oriented reforms.

\section{REFERENCES}

[1] YU Bo, "Study on Teaching Problems and Improvement Measures of Introduction to E-commerce", Theory Research, vol. 24, 2014, pp. 214-216.

[2] LIU Fu-de, CHEN Xiao-hui, "Exploration of multidimensional opening Teaching Method of Introduction to E-commerce", EBusiness Journal, vol. 10, 2013, pp. 78-79.

[3] LIU He-ying, "E-commerce entrepreneurial curriculum Teaching Model", Industrial \& Science Tribune, vol. 24, 2012, pp. 182-183.

[4] ZHU Wen-xi, "E-commerce teaching reform aiming at innovation and pioneering", E-Business Journal, vol. 9, 2014, pp. 79-83.

[5] YANG Hong-xia, LI Lai-zhi, “Teaching mode network environment of e-commerce research", Economic Research Guide, vol. 19, pp. 272-273. 2012, 